\title{
Evaluation of Different Weed Management Practices and Crop Geometry on Weed Control Efficiency and Yield of Direct (Dry) Seeded Rice (Oryza sativa L.)
}

\author{
Vasundhara Kaushik*, S. P. Singh and Sirazuddin \\ Department of Agronomy, G. B. Pant University of Agriculture and Technology, \\ Pantnagar, Uttarakhand, Pin code- 263145, India \\ *Corresponding author
}

Keywords

Direct seeded rice,

Grain yield,

Herbicides, Row

spacing, Weed

management

practices

Article Info

Accepted:

26 July 2020

Available Online:

10 August 2020

\section{A B S T R A C T}

A field experiment was conducted during Kharif season of 2017 in $\mathrm{D}_{2}$ block at Norman E. Borlaug Crop Research Centre of G. B. Pant University of Agriculture and Technology, Pantnagar intending to find out the efficacy of different pre and post -emergence herbicides for controlling the weeds and also their effect on direct (dry) seeded rice in three planting geometries. The maximum weed control efficiency $96.59,72.81$, and 82.32 percent was obtained at a row spacing of $25 \mathrm{~cm}$ with the pre- and post- emergence application of pendimethalin $1 \mathrm{~kg} / \mathrm{ha} f b$ penoxsulam $22.5 \mathrm{~g} / \mathrm{ha}$ at 40,60 and 80 DAS. Row spacing of $25 \mathrm{~cm}$ recorded the highest grain yield (4.2 t/ha) which was comparable to $20 \mathrm{~cm}$ row spacing and significantly superior to $30 \mathrm{~cm}$ row spacing. Application of pendimethalin $1 \mathrm{~kg} / \mathrm{ha}$ $f b$ penoxsulam $22.5 \mathrm{~g} / \mathrm{ha}$ recorded highest grain yield $(4.4 \mathrm{t} / \mathrm{ha})$ after weed free. Highest B:C ratio (2.0) was obtained with $25 \mathrm{~cm}$ spacing along with the preemergence application of pendimethalin (1.0 kg/ha) $f b$ post-emergence penoxsulam $(22.5 \mathrm{~g} / \mathrm{ha})$ which was followed by the row spacing of $20 \mathrm{~cm}$ along with the post-emergence application of cyhalofop-butyl + penoxsulam (Readymix) $150 \mathrm{~g} / \mathrm{ha}(1.7)$.

\section{Introduction}

Rice is vital to more than half of the world's population. It is a major cereal crop and staple food for more than half of the world's population. About $90 \%$ of the world's rice is produced and consumed in Asia (FAO, 2014). Rice is grown by various methods depending upon the resource availability like direct dry seeding in unpuddled beds, direct seeding in puddled beds and transplanting in puddled beds. Considering the difficulties in transplanting it is necessary to look for the substitute of rice establishment methods. Taking the advantages of saving water and labour and increasing system productivity, 
dry direct-seeded rice has been believed to be an optimal option for rice production (Kumar and Ladha, 2011). Direct-seeded rice systems are subjected to much higher weed pressure than puddled transplanted rice systems (Rao et al., 2007), in which weeds are suppressed by standing water and transplanted rice seedlings, which provide 'head start' over germinating weed seedlings. In direct-seeded rice, weeds emerge simultaneously with crop seedlings and grow more quickly in moist soil than in puddled transplanted rice (Khaliq and Matloob, 2011), resulting in severe competition for resources to the crop. Therefore, weeds present the main biological constraint to the success of direct-seeded rice (Chauhan, 2012), and failure to control weeds results in yield losses ranging from 50 to 90 $\%$ (Chauhan and Johnson, 2011; Chauhan and Opena, 2012).Crop geometry is another factor that affects the crop weed competition and grain yield and it has been hypothesized that narrow row spacing may decrease the interval of critical weed competition periods. Herbicides with different crop geometries may show the different effects on crop, hence standardization of herbicides and their application time with different row spacing is essential for efficient weed management and crop growth and development.

\section{Materials and Methods}

A field experiment was conducted during Kharif season of 2017 in $\mathrm{D}_{2}$ block at Norman E. Borlaug Crop Research Centre of G. B. Pant University of Agriculture and Technology, Pantnagar intending to find out the efficacy of different pre and post emergence herbicides for controlling the weeds and also their effect on direct (dry) seeded rice in three planting geometries. Three planting geometries $(\mathrm{S} 1-20 \mathrm{~cm}, \mathrm{~S} 2-25$ $\mathrm{cm}$ and $\mathrm{S} 3-30 \mathrm{~cm}$ ) in main plots and four weed management practices (W1- Weedy check, W2- Pendimethalin @ $1 \mathrm{~kg} / \mathrm{ha} f b$
Penoxsulam@22.5 g/ha, W3- Cyhalofopbutyl + Penoxsulam @150 g/ha, W4- weedfree) in subplots were studied in a split plot design (SPD), with four replications.

Seeds of "Pant dhan 18 " were sown in lines at a seed rate of $40 \mathrm{~kg} / \mathrm{ha}$ with a different row spacing of $20 \mathrm{~cm}, 25 \mathrm{~cm}$ and $30 \mathrm{~cm}$ apart manually in all plots. Pendimethalin on the next day of sowing and post-emergence herbicides penoxsulam and cyhalofop-butyl at 20 DAS was applied using 500 litres of water by using knapsack sprayer fitted with flat fan nozzle. The weed control efficiency of all the treatments was calculated in relation to reduction of total dry weight of weeds in the treated plot over the weedy plot which was expressed as percentage. Weed control efficiency was calculated by using the following formula:

DW of weeds in weedy plot - DW of weeds in treated plot

$$
\begin{aligned}
& \operatorname{WCE}(\%)=\longrightarrow 100 \\
& \text { DW of weeds in weedy plot }
\end{aligned}
$$

The number of panicles was counted from the marked plants observation area of one-meter row length before harvesting and effective shoots $\left(\mathrm{m}^{2}\right)$ were worked out. This was converted to per unit area and expressed as the number of panicles per square meter. The same 5 panicles marked for plant height were manually threshed. The numbers of total grains were counted and the number of grains per panicle was calculated by averaging 5 panicles. The number of total grains from the sampled panicles was counted and their weight was recorded. Then grain weight was expressed by adjusting into 1000 grain weight in gram. In gross plot $(5 \mathrm{~m} \times 3 \mathrm{~m})$ area, there were $12,15,9$ rows in a respective row spaced treatment, out of which 8,7 and 6 rows, respectively were harvested as net plot area $(4 \mathrm{~m} \times 2 \mathrm{~m}),(4 \mathrm{~m} \times 1.75 \mathrm{~m}),(4 \mathrm{~m} \times 1.5 \mathrm{~m})$ and remaining rows were left as border. The grain 
harvested from the net plot area from each plot was recorded and expressed as tons per hectare. The weight of total produce (biological yield) per net plot as mentioned in grain yield parameter was weighed before threshing. The straw yield was calculated by subtracting grain yield from biological yield and expressed as tons per hectare. Harvest index (HI) was worked out by using the following formula:

$$
\mathrm{HI}=\frac{\text { Grain yield }}{\text { Biological yield }} \times 100
$$

The common cost of production was calculated, and the additional weed management treatment was calculated. The benefit cost ratio was calculated to assess the economics of the crop produce influenced by different treatments.

\section{Results and Discussion}

\section{Weed control efficiency}

The maximum weed control efficiency (Table 1) $96.59,72.81$, and 82.32 per cent was obtained at a row spacing of $25 \mathrm{~cm}$ with the pre- and post-emergence application of pendimethalin $1 \mathrm{~kg} /$ ha $f b$ penoxsulam 22.5 $\mathrm{g} / \mathrm{ha}$ at 40, 60 and 80 DAS. The maximum weed control efficiency was recorded in the row spacing of $25 \mathrm{~cm}$ with the pre- and post emergence application of pendimethalin $1 \mathrm{~kg} / \mathrm{ha} f b$ penoxsulam $22.5 \mathrm{~g} / \mathrm{ha}(96.59 \%)$ followed by row spacing of $20 \mathrm{~cm}$ with cyhalofop-butyl + penoxsulam (Readymix) $150 \mathrm{~g} / \mathrm{ha}(86.75 \%)$ at $40 \mathrm{DAS}$.

At all the stages of the crop growth, row spacing of $25 \mathrm{~cm}$ with the application of pendimethalin $1 \mathrm{~kg} / \mathrm{ha} f b$ penoxsulam 22.5 $\mathrm{g} / \mathrm{ha}$ proved to be better in terms of weed control efficiency over the other treatments. This might be due to the suppression of weed more effectively through the pre and postemergence herbicide. Weedy check plots recorded the lowest weed control efficiency. Among the weed control treatments, weed free plots resulted in the highest weed control efficiency $(100 \%)$ all the growth stages of the crop. These findings are in support from the observation of (Singh et al., 2007).

\section{Yield contributing characters}

\section{0-grain weight}

Variation in thousand grain weight (Table 2) attributed to different row spacing was found non-significant. All weed management practices provided significantly better conditions. Weed free recorded the highest 1000-grain weight (24.63g) which was significantly higher than the other treatments. Test weight is a character mostly governed by the genetic influence of the crop and hence, environmental and managerial factors usually have less influence.

\section{Number of grains/panicle}

The number of grains/panicle (Table 2) exhibited significant variation owing to different row spacings. Row spacing of $25 \mathrm{~cm}$ produced a significantly higher number of grains per panicle as compared to the other two row spacings. Among the herbicidal treatments, pendimethalin $1 \mathrm{~kg} / \mathrm{ha} f b$ penoxsulam $22.5 \mathrm{~g} / \mathrm{ha}$ and weed free are at par with each other and significantly higher than the other treatments. The highest crop growth rate was also recorded with the same treatment.

\section{Number of panicles $/ \mathrm{m}^{2}$}

Different row spacing of rice did not affect the number of panicles $/ \mathrm{m}^{2}$ (Table 2) significantly. Numerically highest number of panicles $/ \mathrm{m}^{2}$ recorded in $25 \mathrm{~cm}$ row spacing 
and lowest in $20 \mathrm{~cm}$ row spacing, although the difference was non-significant. All the weed management practices produced significantly higher number of panicles/ $\mathrm{m}^{2}$ over the weedy plot. Weed free plot recorded the highest number of panicles/ $\mathrm{m}^{2}$ which was at par with the pendimethalin $1 \mathrm{~kg} / \mathrm{ha} f b$ penoxsulam $22.5 \mathrm{~g} / \mathrm{ha}$ and significantly higher over the cyhalofop-butyl + penoxsulam (Readymix) $150 \mathrm{~g} / \mathrm{ha}$.

\section{Grain yield}

Grain yield (Table 3) was significantly affected by the different row spacings and weed management practices. Among different row spacing, $25 \mathrm{~cm}$ spacing obtained the highest grain yield (4.2 t/ha) which was comparable to 20 spacing and significantly superior to $30 \mathrm{~cm}$ spacing because of the optimum spacing which resulted in more effective tillers and more number of grains/panicle subsequently higher grain yield.

All the weed control measures applied plots produced significantly higher grain yield than a weedy check. Application of pendimethalin $1 \mathrm{~kg} / \mathrm{ha} \mathrm{fb}$ penoxsulam $22.5 \mathrm{~g} / \mathrm{ha}$ recorded the highest grain yield $(4.4 \mathrm{t} / \mathrm{ha})$ after weed free which was comparable to application of cyhalofop-butyl + penoxsulam (Readymix) $150 \mathrm{~g} / \mathrm{ha}$. It might be due to higher no. of panicles $/ \mathrm{m}^{2}$ and no. of grains/panicle obtained with the pre-emergence application of pendimethalin $1 \mathrm{~kg} / \mathrm{ha} f b$ penoxsulam 22.5 $\mathrm{g} / \mathrm{ha}$ and $25 \mathrm{~cm}$ of spacing. Pre-emergence application of pendimethalin $1 \mathrm{~kg} / \mathrm{ha}$ supplemented with the post-emergence herbicide produced markedly higher grain yield and lesser weed dry weight as compared to other treatments Bahar and Singh, (2004).

\section{Straw yield}

Differences in straw yield (Table 3) due to different row spacings were found significant.
Among different row spacings, $25 \mathrm{~cm}$ spacing obtained the highest straw $(8.3 \mathrm{t} / \mathrm{ha})$ yield which was comparable to $20 \mathrm{~cm}$ spacing and significantly superior to $30 \mathrm{~cm}$ spacing. Within weed management practices, the highest straw yield (9.2 t/ha) was recorded with Readymix application of cyhalofop-butyl + penoxsulam @ 150 g/ha which was comparable to application of pendimethalin 1 $\mathrm{kg} / \mathrm{ha} f b$ penoxsulam $22.5 \mathrm{~g} / \mathrm{ha}$ and weed free situation.

\section{Biological yield}

Biological yield (Table 3) did not differ significantly owing to different row spacing. However, maximum biological yield was obtained under $25 \mathrm{~cm}$ row spacing was followed by 20 and $30 \mathrm{~cm}$ row spacing.

All the weed management practices applied plots produced significantly higher biological yield than weedy check. Ready mix application of cyhalofop butyl + penoxsulam $150 \mathrm{~g} / \mathrm{ha}$ and weed free were statistically same and at par with pendimethalin $1 \mathrm{~kg} / \mathrm{ha} f b$ penoxsulam $22.5 \mathrm{~g} / \mathrm{ha}$. Weedy plot recorded the lowest grain yield, straw yield, and biological yield.

\section{Harvest index}

Harvest index (Table 3) was found nonsignificant in varying row spacing and weed management practices also.

\section{Economics}

Through the analysis, it was observed that the maximum cost (Table 4) involved in the in case of weed free treatment. Maximum gross return (Table 4) was found under pendimethalin $1 \mathrm{~kg} / \mathrm{ha} f b$ penoxsulam 22.5 $\mathrm{g} / \mathrm{ha}$ and in the weed free treatment with the $25 \mathrm{~cm}$ row spacing. 
Table.1 Effect of different row spacing and WMP on the WCE (\%) at different stages of crop growth

\begin{tabular}{|c|c|c|c|c|}
\hline Symbol & Treatments & 40DAS & 60DAS & 80DAS \\
\hline S1W1 & $20 \mathrm{~cm} \times$ Weedy & 0 & 0 & 0 \\
\hline S1W2 & $\begin{array}{l}\text { 20cm } \times \text { Pendimethalin@ } 1 \mathrm{~kg} / \mathrm{ha} \mathrm{fb} \text { Penoxsulam } \\
@ 22.5 \mathrm{~g} / \mathrm{ha}\end{array}$ & 86.75 & 72.45 & 62.35 \\
\hline S1W3 & 20cm $\times$ Cyhalofop-butyl + Penoxsulam @ 150g/ha & 69 & 61.9 & 65.76 \\
\hline S1W4 & $20 \mathrm{~cm} \times$ Weed free & 100 & 100 & 100 \\
\hline S2W1 & $25 \mathrm{~cm} \times$ Weedy & 0 & 0 & 0 \\
\hline S2W2 & $\begin{array}{l}25 \mathrm{~cm} \times \text { Pendimethalin@ } 1 \mathrm{~kg} / \mathrm{ha} f b \text { Penoxsulam } \\
@ 22.5 \mathrm{~g} / \mathrm{ha}\end{array}$ & 96.59 & 72.81 & 82.32 \\
\hline S2W3 & 25cm× Cyhalofop-butyl + Penoxsulam @ 150g/ha & 70.27 & 53.19 & 53.67 \\
\hline S2W4 & $25 \mathrm{~cm} \times$ Weed free & 100 & 100 & 100 \\
\hline S3W1 & $30 \mathrm{~cm} \times$ Weedy & 0 & 0 & 0 \\
\hline S3W2 & $\begin{array}{l}\text { 30cm× Pendimethalin@ } 1 \mathrm{~kg} / \mathrm{ha} f b \text { Penoxsulam } \\
@ 22.5 \mathrm{~g} / \mathrm{ha}\end{array}$ & 62.87 & 55.14 & 72.19 \\
\hline S3W3 & 30cm $\times$ Cyhalofop-butyl + Penoxsulam @ 150g/ha & 55.47 & 39.71 & 47.94 \\
\hline S3W4 & $30 \mathrm{~cm} \times$ Weed free & 100 & 100 & 100 \\
\hline
\end{tabular}

Table.2 Effect of different row spacing and WMP on the yield attributes of aerobic rice

\begin{tabular}{|c|c|c|c|}
\hline Treatments & Panicle $/ \mathbf{m}^{2}$ & $\begin{array}{c}\text { No. of } \\
\text { grains/panicle }\end{array}$ & $\begin{array}{c}1000 \text { grain weight } \\
\text { (g) }\end{array}$ \\
\hline \multicolumn{4}{|l|}{ A. Row spacing(cm) } \\
\hline 20 & 185 & 99 & 23.21 \\
\hline 25 & 187 & 106 & 23.45 \\
\hline 30 & 186 & 102 & 23.41 \\
\hline SEm \pm & 2.78 & 0.78 & 0.16 \\
\hline C.D at $5 \%$ & NS & 2.78 & NS \\
\hline \multicolumn{4}{|l|}{ B. Weed management } \\
\hline Weedy & 106 & 98 & 22.74 \\
\hline Pendimethalin@1kg/ha fb & 218 & 105 & 23.35 \\
\hline Penoxsulam @22.5 g/ha & & & \\
\hline Cyhalofop-butyl + & 199 & 101 & 22.71 \\
\hline Penoxsulam @ 150g/ha & 222 & 105 & 24.63 \\
\hline Weed free & 3.44 & 0.88 & 0.17 \\
\hline SEm \pm & 10.04 & 2.59 & 0.51 \\
\hline CD at $5 \%$ & & & \\
\hline
\end{tabular}


Table.3 Effect of different row spacing and WMP on the grain yield (t/ha), straw yield (t/ha), biological yield (t/ha) and grain: straw ratio

\begin{tabular}{|c|c|c|c|c|}
\hline Treatments & $\begin{array}{l}\text { Grain yield } \\
\text { (t/ha) }\end{array}$ & $\begin{array}{l}\text { Straw yield } \\
\text { (t/ha) }\end{array}$ & $\begin{array}{c}\text { Biological } \\
\text { yield (t/ha) }\end{array}$ & $\begin{array}{c}\text { Harvest } \\
\text { index }\end{array}$ \\
\hline \multicolumn{5}{|l|}{ Row spacing(cm) } \\
\hline $\begin{array}{l}20 \\
25 \\
30 \\
\text { SEm } \pm \\
\text { C.D at } 5 \%\end{array}$ & $\begin{array}{c}4.0 \\
4.2 \\
3.4 \\
0.25 \\
0.72\end{array}$ & $\begin{array}{c}8.0 \\
8.3 \\
7.1 \\
0.39 \\
0.86\end{array}$ & $\begin{array}{l}12.0 \\
12.5 \\
10.6 \\
0.54 \\
\text { NS }\end{array}$ & $\begin{array}{c}33.56 \\
37.37 \\
31.50 \\
1.63 \\
\mathrm{NS}\end{array}$ \\
\hline \multicolumn{5}{|l|}{ Weed management } \\
\hline $\begin{array}{l}\text { Weedy } \\
\text { Pendimethalin@1 } 1 \mathrm{~kg} / \mathrm{ha} \mathrm{fb} \\
\text { Penoxsulam @ } 22.5 \mathrm{~g} / \mathrm{ha} \\
\text { Cyhalofop-butyl + Penoxsulam @ } \\
150 \mathrm{~g} / \mathrm{ha} \\
\text { Weed free } \\
\text { SEm } \pm \\
\text { CD at 5\% }\end{array}$ & $\begin{array}{c}2.1 \\
4.4 \\
\\
4.3 \\
4.8 \\
0.14 \\
0.42\end{array}$ & $\begin{array}{c}4.5 \\
8.8 \\
\\
9.2 \\
8.7 \\
0.44 \\
1.05\end{array}$ & $\begin{array}{c}6.6 \\
13.2 \\
\\
13.5 \\
13.5 \\
0.48 \\
1.41\end{array}$ & $\begin{array}{c}31.33 \\
35.25 \\
\\
33.50 \\
36.50 \\
2.34 \\
\mathrm{NS}\end{array}$ \\
\hline
\end{tabular}

Table.4 Effect of different row spacing and WMP on the cost of cultivation, gross return, net return and $\mathrm{B}$ : $\mathrm{C}$ ratio by crop at harvest

\begin{tabular}{|c|c|c|c|c|c|c|}
\hline \multicolumn{2}{|r|}{ Treatments } & \multirow[b]{2}{*}{$\begin{array}{l}\text { Dose } \\
\text { (g/ha) }\end{array}$} & \multirow[b]{2}{*}{$\begin{array}{c}\begin{array}{c}\text { Cost of } \\
\text { cultivation } \\
\text { (Rs/ha) }\end{array} \\
\text { (R) }\end{array}$} & \multirow[b]{2}{*}{$\begin{array}{l}\text { Gross } \\
\text { return } \\
\text { (Rs/ha) }\end{array}$} & \multirow[b]{2}{*}{$\begin{array}{l}\text { Net } \\
\text { return } \\
\text { (Rs/ha) }\end{array}$} & \multirow[b]{2}{*}{$\begin{array}{l}\mathrm{B}: \mathrm{C} \\
\text { ratio }\end{array}$} \\
\hline $\begin{array}{c}\text { Row } \\
\text { spacing }(\mathbf{c m})\end{array}$ & Weed management & & & & & \\
\hline s20 & Weedy check & - & 22480 & 32395 & 9915 & 0.4 \\
\hline 20 & Pendimethalin $f b$ Penoxsulam & $1000 \mathrm{fb} 22.5$ & 27,060 & 70060 & 43000 & 1.5 \\
\hline 20 & Cyhalofop-butyl + Penoxsulam & 150 & 24980 & 66650 & 41670 & 1.6 \\
\hline 20 & $\begin{array}{l}\text { Weed free (Pendimethalin+2HW } \\
20 \text { and } 40 \text { DAS) }\end{array}$ & $\begin{array}{l}1000 f b 20 \\
\text { and } 40\end{array}$ & 27,300 & 75950 & 48650 & 1.7 \\
\hline 25 & Weedy check & - & 22840 & 46965 & 24485 & 1.0 \\
\hline 25 & Pendimethalin + Penoxsulam & $1000 \mathrm{fb} 22.5$ & 27,060 & 83235 & 56175 & 2.0 \\
\hline 25 & Cyhalofop-butyl + Penoxsulam & 150 & 24980 & 68665 & 43685 & 1.7 \\
\hline 25 & $\begin{array}{l}\text { Weed free (Pendimethalin+2HW } \\
\text { at } 20 \text { and } 40 \text { DAS) }\end{array}$ & $\begin{array}{l}1000 f b 20 \\
\text { and } 40\end{array}$ & 27,300 & 83700 & 56400 & 2.0 \\
\hline 30 & Weedy check & - & 22840 & 26350 & 3510 & 0.1 \\
\hline 30 & Pendimethalin $f b$ Penoxsulam & $1000 \mathrm{fb} 22.5$ & 27,060 & 58900 & 31840 & 1.1 \\
\hline 30 & Cyhalofop-butyl + Penoxsulam & 150 & 24980 & 60450 & 35470 & 1.4 \\
\hline 30 & $\begin{array}{l}\text { Weed free (Pendimethalin }+2 \mathrm{HW} \\
20 \text { and } 40 \text { DAS) }\end{array}$ & $\begin{array}{l}1000 f b 20 \\
\text { and } 40\end{array}$ & 27,300 & 65100 & 37800 & 1.3 \\
\hline
\end{tabular}


Maximum net return (Table 4) was found under pendimethalin $1 \mathrm{~kg} / \mathrm{ha} f b$ penoxsulam $22.5 \mathrm{~g} / \mathrm{ha}(56175 \mathrm{Rs} / \mathrm{ha})$ after the weed free treatment (56400 Rs/ha). Highest B:C ratio (2.0) (Table 4) was obtained with $25 \mathrm{~cm}$ spacing along with the pre-emergence application of pendimethalin $(1.0 \mathrm{~kg} / \mathrm{ha}) \mathrm{fb}$ post-emergence penoxsulam $(22.5 \mathrm{~g} / \mathrm{ha})$ which was followed by the row spacing of $20 \mathrm{~cm}$ along with the post-emergence application of cyhalofop-butyl + penoxsulam (Readymix) $150 \mathrm{~g} / \mathrm{ha}$ (1.7). Lowest net return, gross return, $\mathrm{B}$ : $\mathrm{C}$ ratio was recorded in the spacing of $30 \mathrm{~cm}$ along with all the weed management practices after the weedy check. This might be due to the lowest grain yield and straw yield in this spacing

\section{References}

Bahar, F.A. and Singh, G. (2004). Effect of herbicides on dry seeded rice and associated weeds. Indian J. Weed Sci. 36(3\&4): 269-2

Chauhan, B.S. and Opena, J. (2012) Effect of tillage systems and herbicides on weed emergence, weed growth, and grain yield in dry-seeded rice systems. Field Crop Res 137:56-69. DOI10.1016/j.fcr.2012.08.016
Chauhan, B.S. (2012). Weed ecology and weed management strategies for dryseeded rice in Asia. Weed Technol. 26: $1-13$.

Chauhan, B.S. and Johnson, D.E. (2011). Row spacing and weed control timing affect yield of aerobic rice. Field Crops Res. 121: 226-231

FAO-Food and Agriculture Organization (2014). FAOSTAT Database. FAO, ROME.www.faostat.fao.org (accessed 20.05.14.).

Khaliq, A. and Matloob, A. (2011). Weed crop competition period in three fine rice cultivars under direct seeded rice culture. Pakistan J. Weed Sci. Res. 17(3): 229-243.

Kumar, V. and Ladha, J.K. (2011). Direct seeding of rice: recent developments and future research needs. Adv Agron 111: 297-413

Rao, A. S., Ratnam, M. and Reddy, T. Y. (2008). Weed Management in Direct seeded Semi Dry Rice. Indian J. Weed Sci. 40 (3 \& 4) :153-156

Singh, V. P., Singh, S.P., Kumar. A, and S.Singh, M.K. (2007). Resource conservation through direct seeding rice and zero tillage of wheat in the IndoGangetic Plains, IRRI.

\section{How to cite this article:}

Vasundhara Kaushik, S. P. Singh and Sirazuddin. 2020. Evaluation of Different Weed Management Practices and Crop Geometry on Weed Control Efficiency and Yield of Direct (Dry) Seeded Rice (Oryza sativa L.). Int.J.Curr.Microbiol.App.Sci. 9(08): 3354-3360. doi: https://doi.org/10.20546/ijcmas.2020.908.386 